\title{
A HANDLIST OF THE WRITINGS OF SIR THOMAS BARLOW
}

\author{
Compiled by ALFRED WHITE FRANKLIN, M.B., F.R.C.P.
}

Barlow wrote chiefly of disease as he saw it in the organs and tissues of his patients, living and dead. Nothing but his classic papers on scurvy will escape the dusty, unread fate of medical ephemera. This handlist preserves at least the names of those medical things that caught his eye and mind; another list, as long, could record meetings attended and speeches made to help his fellow men.

1. On a case of pericardial effusion, in which paracentesis was performed Practitioner, 1873, 11, 265-270.

2. Aneurysm at base of left ventricle of heart Trans. Path. Soc. Lond., 1875, 26, 65-6.

3. Case of acute tuberculosis in a child aged four months Brit. med.J., 1876, 2, 552.

4. Congenital heart disease; two cases Trans. path. Soc. Lond., 1876, 27, 140-2.

5. On a case of tubercle of the pancreas Loc. cit., 173-5.

6. Receding gummata of liver in case of congenital syphilis Loc. cit., 202-3.

7. Case of phlegmonous syphilides Lancet, 1876, $2,637$.

8. Case of sporadic haemophilia Med. Times Gaz., 1876, 2, 591-2.

9. Membranous ophthalmia, confined to one eye Loc. cit., 623.

10. On a case of double hemiplegia, with cerebral symmetrical lesions Brit. med. J., 1877, 2, 103-4.

11. Brain of a microcephalous child Trans path. Soc. Lond., 1877, 28, 8-9.

12. Meningitis, arteritis, and choroiditis in a child the subject of congenital syphilis Loc. cit., 287-291.

13. Gummata on cranial nerves; disease of cerebral arteries; cicatrices of liver and spleen in a case of congenital syphilis Loc. cit., 291-5 1 plate.

14. Enlargement of the spleen and heart disease in a case of congenital syphilis Loc. cit., 353-6.

15. Note on cerebral aneurism subsequent to emboli Med. Times Gaz., 1877, 1, 362.

16. Double otitis-meningitis Loc. cit., 390-1.

17. Case of hysteria with hemianaesthesia and ovarian hyperaesthesia of the opposite side Loc. cit., 537.

18. Alopecia in congenital syphilis Lancet, 1877, 2 , 276-7.

19. Notes on pleuritic effusion in childhood (T. B. and R. W. Parker) Brit. med. J., 1877, 2, 758-760.

20. Case of undescribed eruption in a tuberculous child Trans. clin. Soc. Lond., 1877, 10, 196-8.

21. A case of ovariotomy in a child aged twelve years (T. B. and H. Marsh) Ibid., 1878, 11, 175-9.

22. Analgesia as a diagnostic test of hysteria Med. Times Gaz., 1878, 1, 191-2.

23. On the cervical opisthotonos of infants (S. Gee and T. B.) St. Bart's Hosp. Rep., 1878, 14, 23-42 See Proc. roy. med.-chir. Soc., 1896-7, 1, 114-7.

24. Note on frequency of pleural effusion in infancy Lancet, 1878, 2, 877.

25. Case of urticaria pigmentosa Trans. clin. Soc. Lond., 1879, 12, 72-4.

26. Specimens of bronchial gland disease Trans. path. Soc. Lond., 1879, 30, 254-7.

27. Enlargement of bronchial glands with relation to whooping cough Brit. med. J., 1879, 2, 889.

28. Congenital heart disease; pulmonary stenosis, with dilated pulmonary artery above the stenosis Trans. path. Soc. Lond., 1879, 30, 272-3.

29. Specimens of craniotabes Loc. cit., 332-3.

30. Specimens of disease of skull in congenital syphilis Loc. cit., 333-9. 1 plate.

31. On lesions of the cranial bones in congenital syphilis (illustrated by three living cases) (T. B. and D. B. Lees) Loc. cit., 350-3.

32. Atelectasis of lungs with emphysematous cyst; congenital heart disease Trans. path. Soc. Lond., $1880,31,48-9$.

33. Acute dilatation of heart after scarlatinal dropsy-(?) cardiac thrombosis-right hemiplegia Med. Times Gaz., 1880, 1, 426-7.

34. Letter on The Manchester Children's Hospital and Dr. Humphreys Brit. med. J., 1880, 1, 186.

35. Laryngitis in congenital syphilis Trans. path. Soc. Lond., 1880, 31, 46-8.

36. Malformation of the heart ... (T. B. Peacock and T. B.) Loc. cit., 91 .

37. Gumma of tongue in hereditary syphilis Loc. cit., 101-2.

38. Disease of growing ends of shafts of long bones in congenital syphilis Loc. cit., 229-233.

39. Cranio-tabes associated with congenital syphilitic disease of parietal bone Loc. cit., 236-8.

40. Case of Addison's disease ... Med. Times Gaz., 1881, 1, 124.

41. Pneumonia in an alcoholic subject Loc. cit., 187.

42. Scarlatinal nephritis-meningitis-recovery Loc. cit., 647-8.

43. Hysterical analgesia in children Brit. med. J., 1881, 2, 892-3.

44. Relationship of craniotabes to rickets and congenital syphilis (D. B. Lees and T. B.) Trans. path. Soc. Lond., 1881, 32, 323-8: also Med. Times Gaz., 1880, 2, 611-6.

45. A case of so-called foetal rickets (cretinism) [dyschondroplasia] Loc. cit., 364-8 1 plate.

46. On subcutaneous nodules connected with fibrous structures, occurring in children the subjects of rheumatism and chorea (T. B. and F. Warner) Trans. Int. Congr. med. Lond., 1881, 4, 116-128 Reported Brit. med. J., 1881, $2,554$.

47. Collective investigation committee, Memorandum on acute rheumatism (J. F. Goodhart and T. B.) Brit. med. J., 1882, 1, 594-5.

48. Memorandum on inherited and acquired syphilis (C. Macnamara and T. B.) Ibid., 1882, 2, 1228-1230.

49. Case of extirpation of the kidney for calculous pyelitis (T. B. and R. J. Godlee) Trans. clin. Soc. Lond., 1882, 15, 134-140.

50. [Case of cleido-cranial dysostosis] Proc. roy. med.-chir. Soc., 1882, n.s. 1, 135.

51. Notes on rheumatism and its allies in childhood Brit. med.J., 1883, 2, 509-514.

52. On cases described as " acute rickets" which are probably a combination of scurvy and rickets, the scurvy being an essential, and the rickets a variable, element Med.-chir. Trans., 1883, 66, 159-220 1 plate Abstracted Proc. roy. med.chir. Soc., 1882-3, n.s. 1, 102-4 Reported Brit. med.' J., 1883, 1, 619: Med. Times Gaz., 1883, 1, 395: St. Louis Cour. Med., 1883, 9, 453-5 Reprinted Arch. Dis. Childh., 1935, 10, 223-252.

53. Discussion on Tubercle of the eye Trans. ophthal. Soc. U.K., 1883, 3, 132-5 See Lancet, 1883, $2,924$.

54. Three cases of Raynaud's disease Trans. clin. Soc. Lond., 1883, 16, 179-188.

55. Sclerema neonatorum Loc. cit., 262-3.

56. Case of maniacal delirium treated by the cold douche Lancet, 1884, 1, 9-10.

57. Case of purpura occurring in the course of typhoid fever Loc. cit., 745-7.

58. Case of congenital xanthelasma palpebrarum Trans. path. Soc. Lond., 1884, 35, 405-7 1 plate.

59. Limb-bones, skull, and brain of a case of so-called foetal rickets (? foetal cretinism) Loc. cit., 35, 459-464. 
60. Simple atrophy of the suprarenal capsules and gumma of kidney in a case of Addison's disease Trans. path. Soc. Lond., 1885, 36, 433-6

61. Sequel to paper on three cases of Raynaud's disease Trans. clin. Soc. Lond., 1885, 18, 307312.

62. A case of suppuration around the vermiform appendix treated by abdominal incision (T. B. and R. J. Godlee) Trans. clin. Soc. Lond., 1886, 19, 88-94: Brit. med. J., 1885, 2, 1063: Lancet, 1885, 2, 1143: Med. Times Gaz., 1885, $2,852$.

63. On a case of early disseminated myelitis occurring in the exanthem stage of measles and fatal on the eleventh day of that disease Med.-chir. Trans., 1887, 70, 77-91 2 plates Abstracted Proc. roy. med.-chir. Soc., 1885-6, n.s. 2, 145-9 Reported Brit. med. J., 1886, 2, 923: Lancet, 1886, 2, 919.

64. Ulcers of stomach in a child the subject of general tuberculosis Trans. path. Soc. Lond., 1887, 38, 141-2.

65. Translation of On local asphyxia and symmetrical gangrene of the extremities by Maurice Raynaud IN Selected MonograPhS London: The New Sydenham Society, 1888 [iv], 183 Appendix by the translator 184-199.

66. On a case of acute enlargement of the thyroid in a child Trans. clin. Soc. Lond., 1888, 21, 67-72

67. Case of erythema iris Illustrated med. News, Lond., 1888, 1, 1-2 1 plate.

68. Case of an infant showing signs of rickets, which had probably started during intra-uterine life, continued after birth for a time, and then undergone partial retrogression Trans. clin. Soc. Lond., $1888,21,290-3$

69. Case of diabetes mellitus, in which skin lesions consisting of broad papules and tubercles (? lichen diabeticus) occurred . . . Brit. J. Derm., 1888-9, 1, 3-9 In German Mh. prakt. Derm., $1888,7,1172-1180$.

70. Case of cured subclavian aneurysm Trans. clin. Soc. Lond., 1888-9, 22, 310-3.

71. Case of hemiatrophy of tongue with paralysis of soft palate following an injury to the upper cervical spine, and (?) to the rim of the foramen magnum Loc. cit., 322-7 1 plate.

72. Case of chronic arthritis in a child, characterized by fibrous contraction of several joints and associated with some thickening of the middle of each tibia and with marked enlargement of groups of lymphatic glands Loc. cit., 328-333.

73. Three cases of Raynaud's disease Loc. cit., 413-4.

74. Pseudo-hypertrophic paralysis, with remarkable secondary atrophy and contraction of the muscles of one lower limb Illustrated med. News, Lond. $1889,2,97-8$

75. Some cases of Raynaud's disease Ibid., 3, 73-5, $97-100,125,176-82$ plates.

76. Intubation of the larynx in a case of diphtheria; remarks Lancet, 1890, 2, 618.

77. University College Hospital : Introductory Address Lancet, 1890, 2, 735-6

78. Letter on The late Mr. John Marshall, F.R.S. Brit. med. J., 1891, 1, 553: Lancet, 1891, 1, 572.

79 Discussion on Tuberculosis Brit. med. J., 1891, 2, 413 Abdominal tuberculosis in childhood Ibid. $1892,1,740$ The treatment of enlarged cervical glands Loc. cit., 1144 Heart disease in children Loc. cit., 1148.

80. On the prognosis of chronic alcoholism in the light of its pathology Med. Chron., 1892-3, 17, 215-225.

81. Some clinical remarks on cases in the children's ward of University College Hospital Clin. J., 1893, 1, 125-8 Reprinted Ibid., 1895, 6, 373-6.

82. The Bradshaw lecture on infantile scurvy and its relation to rickets Brit. med. J., 1894, 2, 1029 1034: Lancet, 1894, 2, 1075-1080 In German Zbl.inn. Med., 1895, 16, 505, 529.

83. Primary atrophy of muscles of limbs and trunk Reported Brit. med. J., 1894, 2, 1109: Lancet, 1894, 2, 1157.
84. Discussion on Congenital syphilitic manifestations in bones and joints Brit. med. J., 1895, 2, 699 The nervous sequelae of infectious disease Loc. cit., 706.

85. Non-tuberculous posterior basic meningitis in infants Ibid., 1897, 1, 1091.

86. Case of myopathy, with autopsy, in a boy aet. 5 . Sequel to a case shown as living specimen before the Clinical Society, November, 1894 (T. B. and F. E. Batten) Trans. clin. Soc. Lond., 1899, 32 , 98-106 5 plates.

87. Articles on Raynaud's disease (6, 577-607 1 plate) Erythromelalgia $(6,607-621)$ : Tuberculous meningitis $(7,466-491)$ : Simple meningitis in children (D. B. Lees and T. B.) (7, 492-559 1 plate): In A System of Medicine, edited by T. C. Allbutt, London, 1899.

88. Discussion on Acute leukaemia Med.-chir. Trans., $1901,84,461$.

89. Les progrès de la médecine Rev. sci., Paris, 1902, $4 s ., 18,225-235$.

90. Inheritance of recurrent attacks of jaundice and of abdominal crises, with hepato-splenomegaly (T. B. and H. Batty-Shaw) Trans. clin. Soc. Lond., 1902, 35, 155-163.

91. The study of the natural history of disease, the basis of all advance in its treatment Brit. med. J., 1902, 2, 313-321: Lancet, 1902, 2, 267-274.

92. Discussion on Molluscum fibrosum in children Med.-chir. Trans., 1903, 86, 302.

93. An address on the hospital ideal and on the concentration of early medical studies in London Brit. med. J., 1904, 2, 1-4.

94. The present position of the medical profession in relation to alcohol Quart. J. Inebr., 1905, 27, 234-240.

95. On some of the nervous complications of the specific fevers Brain, 1906, 29, 303-331.

96. Appreciation of Sir William Broadbent Brit. med. $J ., 1907,2,179-180$

97. Presidential address (the work of the Clinical Society of London) Proc. roy. Soc. Med. (clin. sec.), 1907-8, 1, 1-8.

98. A case of rupture of the upper cord of the brachial plexus at birth (T. B. and C. A. Ballance) Loc. cit., 215-8.

99. Introduction to A SCHOOL FOR MOTHERS, published by Horace Marshall Reviewed Brit. med. J., $1907,2,1787$.

100. Note on Thomas Laurence Read, M.R.C.S. Brit. med. $J, 1909,1,379$.

101. The annual address delivered to the Royal College of Physicians on April 1st, 1912 London $19128^{\circ}$ $48 \mathrm{pp}$.

102. President's address delivered at the opening of the seventeenth International Medical Congress Brit. med. J., 1913, 2, 285-6: Lancet, 1913, 2, 363.

103. Discussion on Polioencephalitis and poliomyelitis Brit. med. J., 1913, 2, 483.

104. Letter on Forcible feeding of suffragettes The Times Nov. 15, 1913 Reported Loc. cit., 1393.

105. The annual address delivered to the Royal College of Physicians on April 6, 1914 London 1914 $8^{\circ} 28 \mathrm{pp}$.

106. Appreciation of Arthur E. Barker Brit. med. J., 1916, 1, 638 .

107. Harvey, the man and physician Ibid., 1916, 2, 577-583: Lancet, 1916, 2, 739-746.

108. Appreciation of Sir Victor Horsley Brit. med. J., 1916, 2, 166.

109. Address to the Incorporated Association of Headmasters on the incidence of venereal disease and its relation to school life and school teaching Reported Ibid., 1917, $2,797$.

110. Obituary of W. A. Sturge (1850-1919) Brit. med. J., 1919, 1, 468: Lancet, 1919, 1, 633: Med. Pr., 1919, n.s. 107, 284.

111. Introduction Arch. Dis. Childh., 1926, 1, i-vi.

112. Speech supporting the Presidential speech of thanks, Third International Pediatric Congress, London, 1933 Acta Paediatr., Stockh., 1933, 16, xxxii. 